\title{
AN EXANTHEMATIC DISEASE EPIDEMIC ASSOCIATED WITH COXSACKIEVIRUS B3 INFECTION IN A DAY CARE CENTER
}

\author{
Regina C. MOREIRA(1), Silvana B. CASTRIGNANO(2), Rita de C. C. CARMONA(1), Filumena M. S. GOMES(2), Sueli G. \\ SAES(1), Rosely S. OLIVEIRA(2), Denise F. C. SOUZA(1), Sueko TAKIMOTO(1), Marisa C. L. COSTA(2) \& \\ Eliseu Alves WALDMAN(3)
}

\begin{abstract}
SUMMARY
An epidemic of exanthematic illness in a day care center is described. Ten children aged 7 to 13 months were affected by the illness. The exanthem was characterized by nonconfluent macular or maculopapular lesions that appeared on the face, body and limbs. Fifty percent of the infected children had fever of up to $39^{\circ} \mathrm{C}$ at the beginning of the disease. Coxsackievirus B3 (CB3) was isolated from the stool of one ill child. Paired serum samples were obtained from eight ill children and six of them presented seroconversion to $\mathrm{CB} 3$. Antibodies to $\mathrm{CB} 3$ were detected at titers higher than 16 in a single serum sample collected from the other two patients. Neutralizing antibodies to CB3 were detected in $71.0 \%$ of the contact children.
\end{abstract}

KEYWORDS: Enteroviruses; Epidemiology of enterovirus; Exanthematic disease.

\section{INTRODUCTION}

The enteroviruses comprise four groups and 68 different serotypes related to several syndromes, with meningitis, conjunctivitis, pericarditis and exanthems being the most common manifestations s.

The coxsackieviruses of group B with six different serotypes (B1 to B6) are related to outbreaks of infectious diseases in semi-closed communities presenting mainly the following clinical profile: myocarditis, pericarditis, aseptic meningitis and exanthems 1,4.5.7.8.

Coxsackievirus B3 (CB3) is commonly related to cases of maculopapular eruptions or sometimes petechiae that, in some occasions, can be misinterpreted as the initial phase of meningococcical illness ${ }^{3.5}$. In an extensive review of the literature, no reports were detected about outbreaks caused by CB3 in São Paulo, Brazil.

The aim of this work was to identify, by virus isolation and specific antibody response, the etiologic agent responsible for the outbreak of exanthematic illness that occurred at the day care center of a general hospital in the city of São Paulo.

\section{MATERIAL AND METHODS}

\section{Clinical History and Data}

In December 1988, an outbreak of exanthematic illness occurred at the day care center for general hospital employees of the University of São Paulo, where 10 children aged 7 to 13 months were affected.

The exanthem was characterized by nonconfluent

(1) Instituto Adolfo Lutz; Av. Dr. Arnaldo, 355, 01246-902, São Paulo, SP, Brasil

(2) Hospital das Clínicas da FMUSP, São Paulo, SP, Brazil.

(3) Faculdade de Saúde Pública da USP, São Paulo, SP, Brazil. 
macular or maculopapular lesions that appeared on the face, body and limbs, including foot soles. During the first days of the disease, the face was not always attacked and usually body lesions appeared first, followed by limb lesions.

Fifty percent of the infected children had fever of up to $39^{\circ} \mathrm{C}$ at the beginning of the disease and only one had fever before the exanthem. Adenomegaly was present in eight children with swelling of occipital and/or cervical and/or retroauricular and/or axillary ganglions. Swelling of inguinal ganglions was observed in two cases. We could observe that the number of swollen ganglions had a tendency to increase with the progress of the disease in the follow-up of four children.

On the $7^{\text {th }}$ or $8^{\text {th }}$ day after the onset of the exanthem, four of ten ill children were submitted to their last examination. One child had not yet been restored to health; two of them had petechiae in the upper and lower limbs and one was healed.

The day care center receives children between 3 to 35 months old and consists of four nursery rooms (R-1, $\mathrm{R}-2, \mathrm{R}-3$, and R-4), and other 5 rooms to older children. The outbreak occurred in children attending R-3 and R-4.

Since the incubation period of enteroviruses lasts about five days ${ }^{4}$ and the first case was confirmed on December $10^{\text {th }}$, any child who was attended R-2, R-3 and R-4 for at least one day between December 5 and 31 was considered to be a contact. On this basis there were 43,34 and 38 contacts in R-2, R-3 and R-4, respectively, aged 6 to 16 months old. No sign or symptom of the disease was observed in any of these children.

\section{Etiological Study}

\section{A - Detection of enterovirus in stool specimens.}

Fecal specimens were collected from two children soon after the eruption of the exanthem.

The virus was isolated by inoculating clinical specimens into tubes containing cell cultures of African green monkey kidney (Vero), human embryonic rhabdomyosarcoma (RD) and human larynx carcinoma (HEp2). Successive passages of the inoculated material were made until the appearance of the characteristic cytopathic effect of enterovirus infection. In negative samples three blind serial passages were made.

The positive cultures were frozen and later thawed, titrated and identified by the technique of neutralization in cell culture, using a serum pool standardized by Lim and Benyesh-Melnick (LBM) ${ }^{6}$.

\section{$B$ - Antibody titration in sera}

Eighty-five serum samples from 72 children were tested. Sixteen samples were collected during the outbreak and the other 69 , seven months later.

The children were divided into two groups:

Group 1 - Comprised ten children that presented exanthem. Paired serum samples were collected from eight of them. The first sample was collected during the acute phase of the disease and the second was obtained in the convalescent phase. A third serum sample was obtained from five of them seven months after the outbreak. Two of the 10 children had only a single sample collected 7 months after the outbreak.

Group 2 - This group consisted of 115 children considered to be contacts since they had attended on rooms R-2, R-3 or R-4 during the outbreak, but did not present any specific clinical sign of the disease. The sera from 62 of these contacts were collected seven months after the outbreak.

The paired samples from the children of group 1 were tested for the presence of antibody to coxsackieviruses of group B (B1 to B6), coxsackievirus A9 and echovirus serotypes 6 and 9 .

The serum samples of children from groups 1 and 2 collected seven months after the outbreak were analyzed for the presence of antibodies to CB3.

The technique of neutralization in HEp-2 cell culture was used to detect the presence of antibodies to enteroviruses, as described by GRANDIEN et al ${ }^{6}$. The test was performed in flat bottom microplates, using 100 TICD- 50 dose of the standard virus and of the CB3 isolated in the laboratory (CB3 IAL).

\section{RESULTS}

CB3 was isolated and identified from the stool of one child who presented exanthem. This viral strain (CB3 IAL) was used as antigen for the determination of antibody titers in serologic tests.

Seroconvertion to CB3 was observed in the convalescent serum from six of eight children belonging to 
group 1. There were no significant difference in antibody titers to the other enteroviruses investigated (coxsackieviruses B1, B2, B4, B5 and B6, coxsackievirus $A 9$ and echovirus 6 and 9). The child from whom the viral strain was isolated presented seroconversion to $\mathrm{CB} 3$.

The results of analysis of the third serum samples collected from five children of group 1 seven months after the outbreak were as follows: neutralizing antibodies to CB3, of titers 32 to 256 , were detected for both the standard strain and the strain isolated in the laboratory during the outbreak (CB3 IAL). One child, who did not present a significant enhancement in antibody titer at the time of the outbreak, presented a titer as high as 256 in the sample collected seven months after the outbreak.

Two patients belonging to group 1 from whom only a single serum sample was obtained had antibody titers of 16 and 64 to $\mathrm{CB} 3$ standard virus and of 32 and 256 to CB3 IAL seven months after the outbreak.

Of the 21 serum samples from group 2 children, belonging to R-2, 14 presented antibody titers to both standard $\mathrm{CB} 3$ and $\mathrm{CB} 3 \mathrm{IAL}$ with geometric mean titers of 13.18 to the standard virus and 20.4 to CB3 IAL.

Antibodies to CB3 were detected in the sera of 14 of the 18 children from R-3 belonging to group 2, and the geometric mean titers were 25.7 to the standard virus and 33.8 to $\mathrm{CB} 3 \mathrm{IAL}$.

Of 23 serum samples obtained from R-4 children, 16 were positive for $\mathrm{CB} 3$ and the geometric mean titers were 22.9 to the standard strain and 33.8 to CB3 IAL.

\section{DISCUSSION}

The participation of enteroviruses as etiologic agents of several childhood syndromes has been widely described in developed countries of the world but in our country these investigations are rare due to the lack of an appropriate viral laboratory structure.

ZANATE et al ${ }^{10}$, in a study on the circulation of enteroviruses in day care centers, kindergartens and orphanages, observed that the group B coxsackieviruses were predominant agents in these communities, and could be isolated from bed clothes, plates, glasses, floor, walls and tables.
In 1986, STRIKAS et al ${ }^{9}$ reported the occurrence of ten to fifteen million of annual cases of enterovirus infections in the United States, without including those caused by polioviruses.

These results support our finding that CB3 was the responsible agent for the outbreak of exanthematic disease that occurred at a day care center in the city of São Paulo. Although the CB3 was isolated from only one child, serological conversion to the isolated virus was obtained in the convalescent sera of paired samples from six of eight children analyzed at the time of the outbreak.

Two of ten children with exanthem from whom sera were collected only in July 1989 presented high titers of antibodies to CB3. One child with exanthem did not show seroconversion at the time of the outbreak but presented increased titers of antibodies to $\mathrm{CB} 3$ seven months after the outbreak. So we can conclude that 9 children presented seroconvertion to CB3.

CANBY et al ${ }^{3}$ described the association of $\mathrm{CB} 3$ in cases of exanthem with petechial eruptions and called attention to the fact that this type of clinical manifestation has medical importance since it may simulate meningococcal infections in the early stages. No reports about this association are available for Brazil. In our study, the seroconversion to CB3 was observed in one of the two children with petechiae. The infection could not be confirmed in the other child because antibodies to CB3 were not detected in the first two serum samples and a third sample could not be obtained.

Sixty-two serum samples from the contact children attending the day care center were analyzed and $44(71.0 \%)$ were positive for CB3. It was evident that the antibody titers to CB3 IAL were higher than the titres to standard coxsackievirus strain. This fact can be explained by the greater antibody avidity to this viral antigen, or a slight antigenic difference between these viruses.

The technique of neutralization is the method of choice for the detection of antibodies to enterovirus due to its high sensitivity and specificity ${ }^{6}$. By the obtained results it is possible to infer that for each detected clinical case, asymptomatic infection occurred in four cases since a large number of contact children presented positive serology $(71.0 \%)$ with no specific 
symptomatology of the disease. These data confirm the results obtained by other authors indicating that the great majority of enteroviral infections are asymptomatic 5 .

\section{RESUMO}

\section{Epidemia de doença exantemática associada à infeç̧ão causada por coxsackievírus B3 em uma creche.}

É descrita uma epidemia de doença exantemática em uma creche, acometendo 10 crianças de 7 a 13 meses de idade. $\mathrm{O}$ quadro exantemático caracterizou-se por lesões máculo ou maculopapulares não confluentes, que atingiam a face, tronco e pernas. $50 \%$ das crianças infectadas apresentaram febre de até $39^{\circ} \mathrm{C}$, no início da doença. Foi isolado das fezes de uma criança doente o coxsackievírus B3 (CB3). Foram examinados soros pareados de 8 das 10 crianças doentes e em 6 delas demonstrou-se soroconversão para CB3. Duas crianças que apresentaram sintomatologia e que tiveram amostras de sangue colhidas somente 7 meses após a epidemia, apresentaram anticorpos específicos contra o CB3, em títulos superiores a 16. Entre os contatos das crianças doentes, verificou-se que $71,0 \%$ do total apresentaram anticorpos neutralizantes especificos contra o CB3.

\section{REFERENCES}

1. ARTENSTEIN, M. S.; CADIGAN, F. C. \& BUESCHER, E. L. Clinical and epidemiological features of Coxsackie group B virus infections. Ann. intern. Med., 63: 597-603, 1965.
2. BENENSON, A. S. - El control de las enfermedades transmisibles en el hombre. 15. ed. Washington, OPAS/OMS, 1992. p. 132-135.

3. CANBY, J. P. - Petechiae and fever: infection with coxsackievirus group B, type 3: case report. Clin. Pediat. (Phila.), 2: 187-188, 1963.

4. CherRY, J. D. - Viral exanthems. Curr. Probl. Pediat., 13: 1-44, 1983.

5. CHERRY, J. D. - Enteroviruses: poliovirus (Poliomielitis), coxsackieviruses, echoviruses and enteroviruses. In: FEIGIN, R. D \& CHERRY, J. D., ed. Textbook of pediatric infectious diseases Philadelphia, W. B. Saunders Company, 1987. v.2, p. 1729-1790.

6. GRANDIEN, M.; FORSGREN, M. \& EHRNST, A. - Enteroviruses and reoviruses. In: SCHIMIDT, N.J. \& EMMONS, R.W., ed Diagnostic procedures for viral, rickettsial and chlamydial infections. 6. ed. Baltimore, APHA, 1989. p. 513-578.

7. MELNICK, J. L. - Importance and prospects for control of Coxsackievirus and Echovirus infections. In: INTERNATIONAL CONFERENCE ON VACCINES AGAINST VIRAL AND RICKETSIAL DISEASES IN MAN, 1., Washington, Pan American Health Organization, 1967. (Scient. Publ. 147).

8. MELNICK, J. L. - Enterovirus. In: EVANS, A. S., ed. Viral infections of humans - epidemiology and control. 3. ed. New York, Plenum, 1989. p. 191-263.

9. STRIKAS, R. A.; ANDERSON, L. J. \& PARKER, R. A. - Temporal and geographic patterns of isolates of non polio enterovirus in the United States, 1970-1973. J. infect. Dis., 153: 346-351, 1986.

10. ZANATE, O.; COTOR, F.; AVRAM, G.; IVAN, A. \& NASTASE, M. - Surveillance of enterovirus circulation in children communities. Rev. roum. Virol., 37: 61-66, 1986.

Recebido para publicação em 04/08/1994. Aceito para publicação em 24/05/1995. 